\title{
VALUATION OF A NEW ENTRANT IN AN OLIGOPOLISTIC MARKET, INCLUDING ITS OPTION TO ABANDON. A REAL-LIFE CASE
}

\author{
Félix Roux \\ Pablo Solana \\ Department of Industrial Engineering, Business Administration and Statistics \\ Escuela Técnica Superior de Ingenieros Industriales \\ Politechnic University of Madrid \\ C/ José Gutiérrez Abascal 2, 28006 Madrid, Spain
}

\author{
Susana Alonso \\ Department of Financial Economics \\ University of Valladolid \\ C/ Trinidad 3, 40001 Segovia, Spain
}

Corresponding author:

Félix Roux

Escuela Técnica Superior de Ingenieros Industriales

Politechnic University of Madrid

C/ José Gutiérrez Abascal 2, 28006 Madrid, Spain

e-mail.froux@etsii.upm.es 


\title{
VALUATION OF A NEW ENTRANT IN AN OLIGOPOLISTIC MARKET, INCLUDING ITS OPTION TO ABANDON. A REAL-LIFE CASE
}

\author{
Félix Roux \\ Pablo Solana \\ Politechnic University of Madrid \\ Susana Alonso \\ University of Valladolid
}

\begin{abstract}
The purpose of this paper is to increase current empirical evidence on the relevance of real options for explaining firm investment decisions in oligopolistic markets. We study an actual investment case in the Spanish mobile telephony industry, the entrant in the market of a new operator, Yoigo. We analyze the option to abandon in order to show the relevance of the possibility of sale the company in an oligopolistic market where competitors are not allowed free entrance. The NPV of the new entrant is calculated as a starting point. Then, and based on the general approach proposed by Copeland and Antikarov (2001), a binomial tree is used to model managerial flexibility in discrete time periods, and value the option to abandon. The strike price of the option is calculated based in incremental EBITDA margins due to selling customers or merging with a competitor.
\end{abstract}

\section{Key words:}

Real Options; Option to abandon; Oligopolistic market; Monte Carlo simulation; Binomial trees 


\section{VALUATION OF A NEW ENTRANT IN AN OLIGOPOLISTIC MARKET, INCLUDING ITS OPTION TO ABANDON. A REAL-LIFE CASE}

\section{INTRODUCTION}

Understanding the valuation of new entrants in a market is a central theme in contemporary business, especially when considering startup companies. It is widely acknowledged that traditional valuations based on Net Present Value (NPV) use estimations with a high degree of uncertainty -such as future cash flows of a company with a limited track record-. The NPV approach neither takes into account the value of some options that these startup companies bear, such as the option to growth or the option abandon the market.

To solve certain restrictions intherent in NPV, we can use real option valuation that emerged from the proposal by Myers in 1977. Real option valuation considers active management of corporate investments and, therefore, the value of their flexibility. In addition, this model takes into account non-monetary outcomes arriving from previous resource allocations and which become as a source of new opportunities for future decisions of the firm.

In this paper we try to increase current empirical evidence on the relevance of real options for explaining firm investment decisions through the study of the entrant of a new competitor in the mobile telecommunications industry. Real Options valuation is very suitable in this industry, due to the future growth opportunities in the telecoms industry, the huge investments required and uncertainties embedded in the market, which are key elements in justifying the real option valuation methodology (Riihimäki, 2009).

Aditionally, the nature of the industry, an oligopolistic market where competitors are not allowed free entrance, is considered in order to evaluate the significance of real options embedded in the investment. Thus, we analyze the option to abandon as the main real option, due to the fact that in this industry, there are economies of scale that allow bigger players enjoy better margins. Consequently, new entrants have the option to sell their business to incumbent companies (already established players), which are able to extract more value from the same customer base, increasing its total size and having access to higher margins. As a recent real example it can be mentioned what happened in the UK in 2009 when T-Mobile and Orange the smaller market players in the mobile market with $15 \%$ and $22 \%$ share respectivelymerged their businesses, creating a much larger company with 28.4 million customers (BBC, 2009). Most likely at the end of the process the brand name will be Orange.

We have evaluated, as a real life investment, the entrant of the fourth operator, Yoigo, 
in the Spanish mobile telecommunications industry. In Europe in general, and in Spain in particular, digital technology upgrades have led to a significant increase in the number of players. Starting with GSM (Global System for Mobile Communication) in the 90s -which is the most popular standard for mobile telephony systems in the world-, and later with the introduction of the UMTS (Universal Mobile Telecommunications System) in the year 2000, there has been a continuous increase in the number of players due to the allocation of radiofrequencies to new standards.

Commonly, these companies have been valuing by simple Discount Cash Flows (DFC) models, forecasting and taking present values of cash flows based in organic growth, and building scenarios according to the probability density function of the variables chosen. However, our analysis of the entrant of Yoigo in the Spanish mobile telephony industry reveals that the sources of value of the investment are not only the present value of future cash flows as expected from the accepted investments, which is valued by DFC models, but also the value provided by the option to sell their business if things do not progress properly once it is up and running, which has to be valued through real options techniques.

We estimate the value of this option to abandon the industry by using the proposal of Copeland and Antikarov (2001), which is adapted to the nature of the investment analysed. One of the most important parameters in the valuation of the option is the strike price which is assumed Yoigo could obtain selling its customer base. To identify this strike price, the increase in value of the entrant due to the increase in its margins at the level of a potential buyer is calculated.

The information required for the case study is gathered from financial publications at the time of the investment, analysts' forecasts, public documents presented to the market by Yoigo and finally, data collected from the professional experience of the authors in the industry. We estimate the investment value on 2006, coinciding with the beginning of Yoigo's operations.

The findings to emerge from the case study provide evidence to support the significance of real options in explaining the decision of Yoigo to entrant in the Spanish mobile telephony industry. The value of the option to abandon endorses the logic of Yoigos's investment decision and contributes to justify the decision taken by the firm.

The remainder of the work is structured as follows. The second section outlines the main features of the industry analysed. The third section provides the description of the methodology framework used for the valuation and the main results. Thus, this section includes, firstly, the valuation of the decision to entrant in the industry without considering 
flexibility, the base case which is valued by DFC model, and secondly considering in an explicit manner the option to abandon which is valued by real options techniques. Also section three present the estimation of the strike price of the option and shows the main results in the option to abandon valuation. The paper closes with a summary of the main conclusions.

\section{OVERVIEW OF THE MOBILE TELEPHONE INDUSTRY IN SPAIN}

In this section we present the Spanish mobile telephone market in order to show its oligopolistic profile, with a limited number of players, high penetration -which tends to lower its growth-, low differentiation of services and the presence of network effects. These elements jointly drive to the existence of economies of scale which are also shown at the end of the section.

\subsection{Limited number of players}

The Spanish mobile telephone market, and major European markets, behaves as a pure oligopoly, consisting of a few companies that offer the same service (Kotler and Keller, 2009). This mainly happens because the frequency bands required to operate are considered a scarce resource, and they are allocated by the Administration. As a consequence, there are currently only four players with frequency ownership in Spain which portrait a pattern of imperfect competition, since only a few companies are able to offer a specific product (Samuelson and Nordhaus, 1986).

Telefónica, under the brand name "Movistar", is the market leader; Vodafone operates under its own brand and is the second player; France Telecom, under the brand name "Orange", is the third player and, since December 2006, Xfera Móviles S.A., under the brand name "Yoigo", launched the fourth mobile operator.

Only those companies are able to manage their own frequencies and consequently deploy their own network, although in some cases they share sites and provide national roaming to each other.

Additionally to these Mobile Network Operators (MNOs) there are a number of Mobile Virtual Network Operators (MVNOs). These are companies that operate using other players' networks and have a completely different operational cost structure. We do not consider these firms in the analysis, not only because of the aforementioned fact but also because their marginal presence in the market- under $2 \%$ market share in terms of number of lines (CMT, 2009). The Figure 1 shows the market share per company in 2008. 
Fig. 1: Market share (\% lines) of mobile operators, Spain 2008 Market Share 2008 \# lines

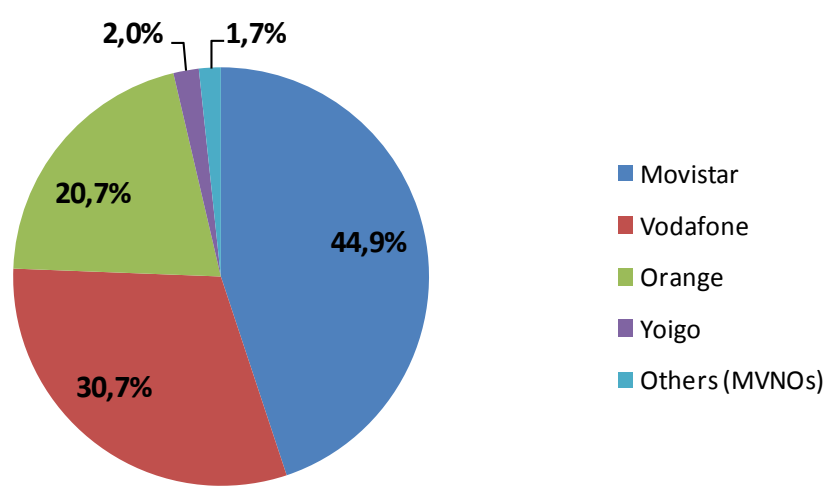

Source: CMT Annual Report, 2009

\subsection{High penetration}

According to Merrill Lynch \& Bank of America Global Wireless Matrix 4Q 2009, the penetration of mobile telephony in Spain, defined as number of subscribers divided per population, reaches $140 \%$, close to Italy -highest in Western Europe- at $147 \%$, and clearly over Germany, United Kingdom and France at 132\%, 126\% and 94\% respectively.

This reflects a very high penetration level at 54.1 millions of lines, shown in Table 1; additionally the growth rate forecasted for years 2010 and 2011 is clearly lower than in previous years, at $1.6 \%$ and $1.1 \%$ respectively. This shows that the market is close to saturation.

Table 1: Total market customers evolution.

\begin{tabular}{|l|ccc|}
\cline { 2 - 4 } \multicolumn{1}{l|}{} & CY09E & CY10E & CY11E \\
\hline Total Market ( & 54055 & 54902 & 55521 \\
mill) & $3.0 \%$ & $1.6 \%$ & $1.1 \%$ \\
\hline
\end{tabular}

\subsection{Low differentiation of services}

Currently there is a low level of differentiation in services, they are mainly limited to voice, short messages (SMSs), and data services that are progressively increasing their weight in the services portfolio. 
But, as Table 2 shows, 72\% of industry revenues in Q3 2009 are due to voice services, in which differentiation is practically nil.

Table 2: Total quarterly revenues in mobile telephony market Spain (million $€$ )

\begin{tabular}{|l|c|c|c|c|c|c|c|c|}
\cline { 2 - 10 } \multicolumn{1}{c|}{} & $\mathbf{2 0 0 7}$ & \multicolumn{5}{c|}{2008} & \multicolumn{3}{c|}{$\mathbf{2 0 0 9}$} \\
\cline { 2 - 10 } \multicolumn{1}{c|}{} & $\mathbf{Q 4}$ & $\mathbf{Q 1}$ & $\mathbf{Q 2}$ & $\mathbf{Q 3}$ & $\mathbf{Q 4}$ & $\mathbf{Q 1}$ & $\mathbf{Q 2}$ & $\mathbf{Q 3}$ \\
\hline Monthly fix fee & 173 & 176 & 197 & 199 & 237 & 222 & 262 & 264 \\
& $5 \%$ & $5 \%$ & $5 \%$ & $5 \%$ & $6 \%$ & $6 \%$ & $7 \%$ & $7 \%$ \\
\hline Voice & 2923 & 2829 & 2852 & 2903 & 2706 & 2554 & 2612 & 2698 \\
& $77 \%$ & $76 \%$ & $76 \%$ & $75 \%$ & $73 \%$ & $72 \%$ & $72 \%$ & $72 \%$ \\
\hline SMSs & 448 & 443 & 420 & 431 & 451 & 426 & 377 & 379 \\
& $12 \%$ & $12 \%$ & $11 \%$ & $11 \%$ & $12 \%$ & $12 \%$ & $10 \%$ & $10 \%$ \\
\hline Data & 225 & 248 & 271 & 296 & 294 & 313 & 344 & 384 \\
& $6 \%$ & $7 \%$ & $7 \%$ & $8 \%$ & $8 \%$ & $9 \%$ & $10 \%$ & $10 \%$ \\
\hline Other & 27 & 28 & 31 & 31 & 33 & 24 & 24 & 31 \\
& $1 \%$ & $1 \%$ & $1 \%$ & $1 \%$ & $1 \%$ & $1 \%$ & $1 \%$ & $1 \%$ \\
\hline Total & $\mathbf{3 7 9 6}$ & $\mathbf{3 7 2 5}$ & $\mathbf{3 7 7 0}$ & $\mathbf{3 8 6 0}$ & $\mathbf{3 7 2 1}$ & $\mathbf{3 5 3 9}$ & $\mathbf{3 6 1 8}$ & $\mathbf{3 7 5 6}$ \\
\hline
\end{tabular}

Source: CMT Quarterly report, 3Q 2009.

Due to this low level of service differentiation, new entrants in the market have needed to compete in price to increase their number of customers, offering the same services at a discount. Figure 2 shows that Orange, the third entrant in the Spanish market, has consistently offered a discount that has had an impact on its average revenue per user.

Fig. 2: Average Revenue Per User (ARPU) evolution, per operator 2003-2008, in $€ /$ month.

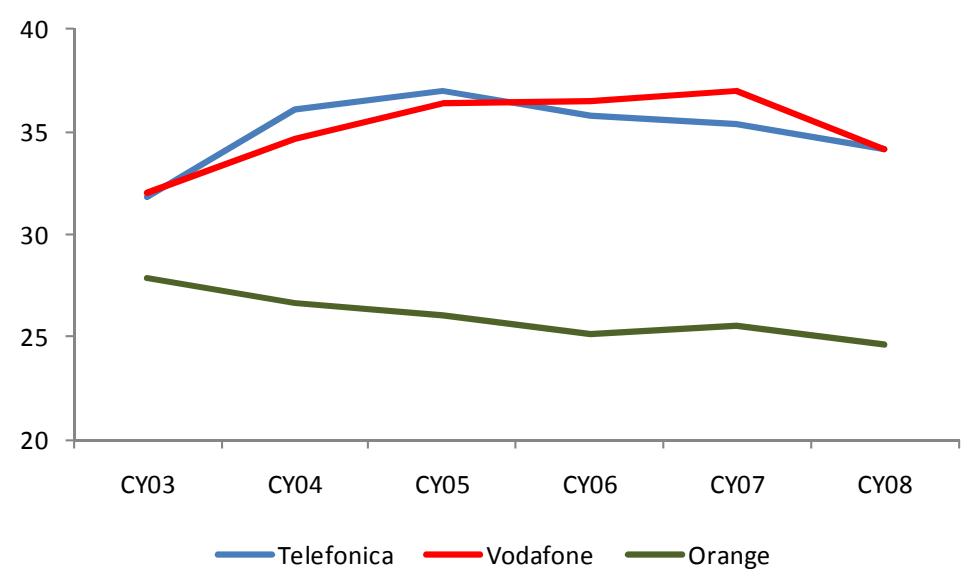

Source: Merrill Llynch \& Bank of America, Global Wireless Matrix 4Q09 and own analysis.

\subsection{Network effects}


Network effects exist if the usage of a product by any user increases or decreases the product's value for other users (Katz and Shapiro, 1985). Technology adoption decisions, in the presence of network effects, are influenced by the size of a provider's existing installed base in the market, as well as by expectations of its future size. The theory suggests that a product value increases due to usage by other users, thus creating a positive network effects (Katz and Shapiro, 1986).

In the european mobile market, network effects are shown in the amounts paid between operators because of terminating calls. Operators with more customers will enjoy higher revenues due to fees of incoming calls finished in their networks, and also they benefit of higher savings as a consequence of "on-net traffic" - calls generated and finished in the same network - that do not pay termination fees. Table 3 shows revenues due to termination rates in Spain, due to traffic generated in competitors' networks. It represents a very relevant amount -over 600 million € per quarter between Q4 2007 and Q3 2009.

Table 3: Revenues due to termination rates in Spain (million $€$ )

\begin{tabular}{|l|c|c|c|c|c|c|c|c|}
\cline { 2 - 9 } \multicolumn{1}{c|}{} & $\mathbf{2 0 0 7}$ & \multicolumn{4}{c|}{2008} & \multicolumn{3}{c|}{ 2009 } \\
\cline { 2 - 9 } \multicolumn{1}{c|}{} & $\mathbf{Q 4}$ & $\mathbf{Q 1}$ & $\mathbf{Q 2}$ & $\mathbf{Q 3}$ & $\mathbf{Q 4}$ & $\mathbf{Q 1}$ & $\mathbf{Q 2}$ & Q3 \\
\hline National & 746 & 720 & 707 & 701 & 644 & 598 & 572 & 585 \\
Voice traffic & 683 & 664 & 652 & 645 & 587 & 546 & 521 & 533 \\
MVNO Traffic & 1 & 1 & 2 & 2 & 2 & 2 & 3 & 3 \\
SMSs & 62 & 55 & 53 & 54 & 56 & 49 & 48 & 49 \\
International & 48 & 50 & 48 & 59 & 42 & 45 & 44 & 53 \\
Voice traffic & 38 & 39 & 37 & 46 & 31 & 30 & 31 & 37 \\
SMSs & 10 & 11 & 11 & 12 & 12 & 15 & 12 & 16 \\
\hline Total & $\mathbf{7 9 5}$ & $\mathbf{7 7 0}$ & $\mathbf{7 5 5}$ & $\mathbf{7 6 0}$ & $\mathbf{6 8 7}$ & $\mathbf{6 4 3}$ & $\mathbf{6 1 6}$ & $\mathbf{6 3 8}$ \\
\hline
\end{tabular}

Source: CMT Quarterly report, 3Q 2009.

\section{METHODOLOGY FRAMEWORK FOR VALUATION}

When investing in new projects, firms worry about the risk that the investment will not pay off, and also about cash flows not meeting expectations. Having the option to abandon a project that does not pay off can be valuable, especially on projects with a significant potential for losses (Damodaran, 2002). Consequently, the fact that a new entrant in the Spanish mobile telecommunications market has the option to sell the company has a value. 
For valuing the option to abandon we apply the methodology proposed by Copeland and Antikarov (2001). On the basis of Samuelson theorem (1965), these authors propose to reduce the sources of uncertainty in investment to a single-value variability of the project without options, which evolves over time as a random walk.

To do that, firstly, an estimation of the investment present value without flexibility is provided, which is calculated by DCF model. The underlying asset of the embedded option is precisely the DCF value of the firm without options.

Then the uncertainty is introduced in an explicit manner as the process followed by the variables identified as uncertain. Once modeled these variables, we used Monte Carlo simulation to generate the distribution in time present value of the investment without flexibility and the standard deviation of its rate of returnis estimated.

Then, the binomial tree is constructed from the underlying values considering the reinvestment of cash flows, and the value of the option is determined.

In Table 4 we present the methodology followed to calculate the option to abandon based upon four steps for the case of Yoigo investment.

Table 4: Diagram of methodology followed.

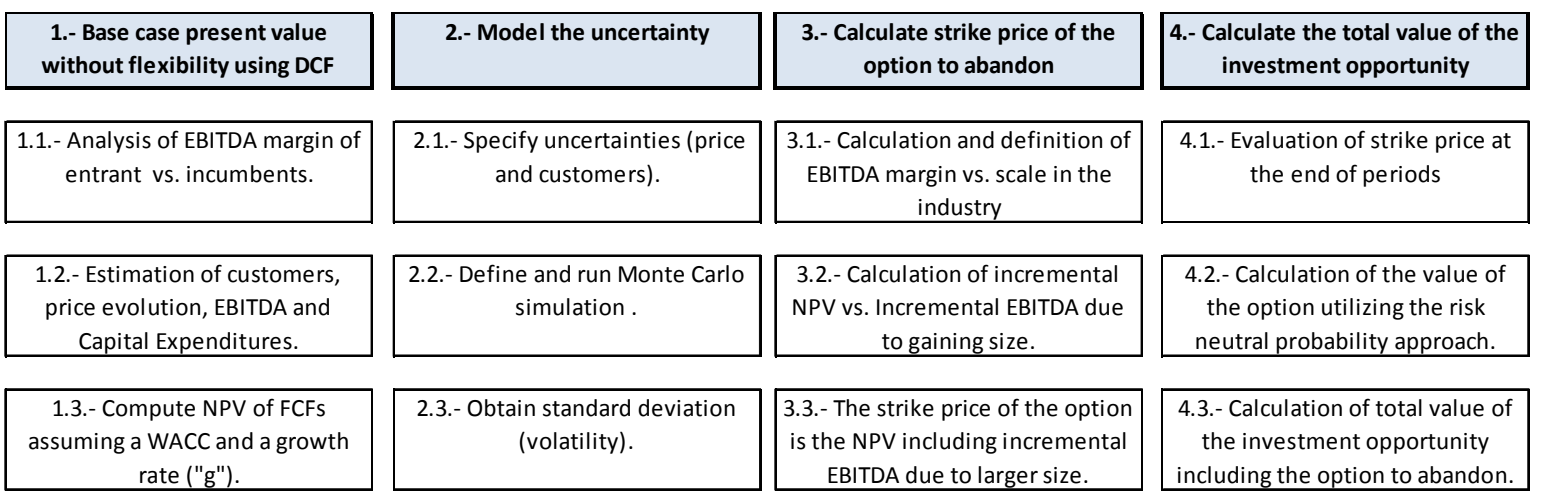

\subsection{First step: Base case present value without flexibility using DFC}

As previously pointed out, there are clear economies of scale in the Spanish mobile telephony industry, because investments in network infrastructure, sales and marketing costs are in the same range due to the fact that the four operators operate nationwide and address the same market.

These economies are evident as per the strong correlation between revenues and EBITDA margin. As shown in the Figure 3, operators with higher in revenues, enjoy higher EBITDA margins. And, consequently, a new entrant with less customers and lower revenues 
would have lower EBITDA margins while in the process of increasing its number of customers. As presented in the attached figure, it is estimated that a new entrant in the Spanish market such as Yoigo, would have an EBITDA margin between 10\% and $20 \%$ until reaching a number of customers over 5 million. In our case we have assumed an optimistic scenario of $20 \%$, in line also with Merrill Llynch \& Bank of America estimations (2009). It also can be appreciated in the figure that increasing those margins could be difficult because of the progressive margin erosion due to market maturity.

Fig. 3: EBITDA Margin (\%) vs. number of customers ('000), Spain 2003 - 2008

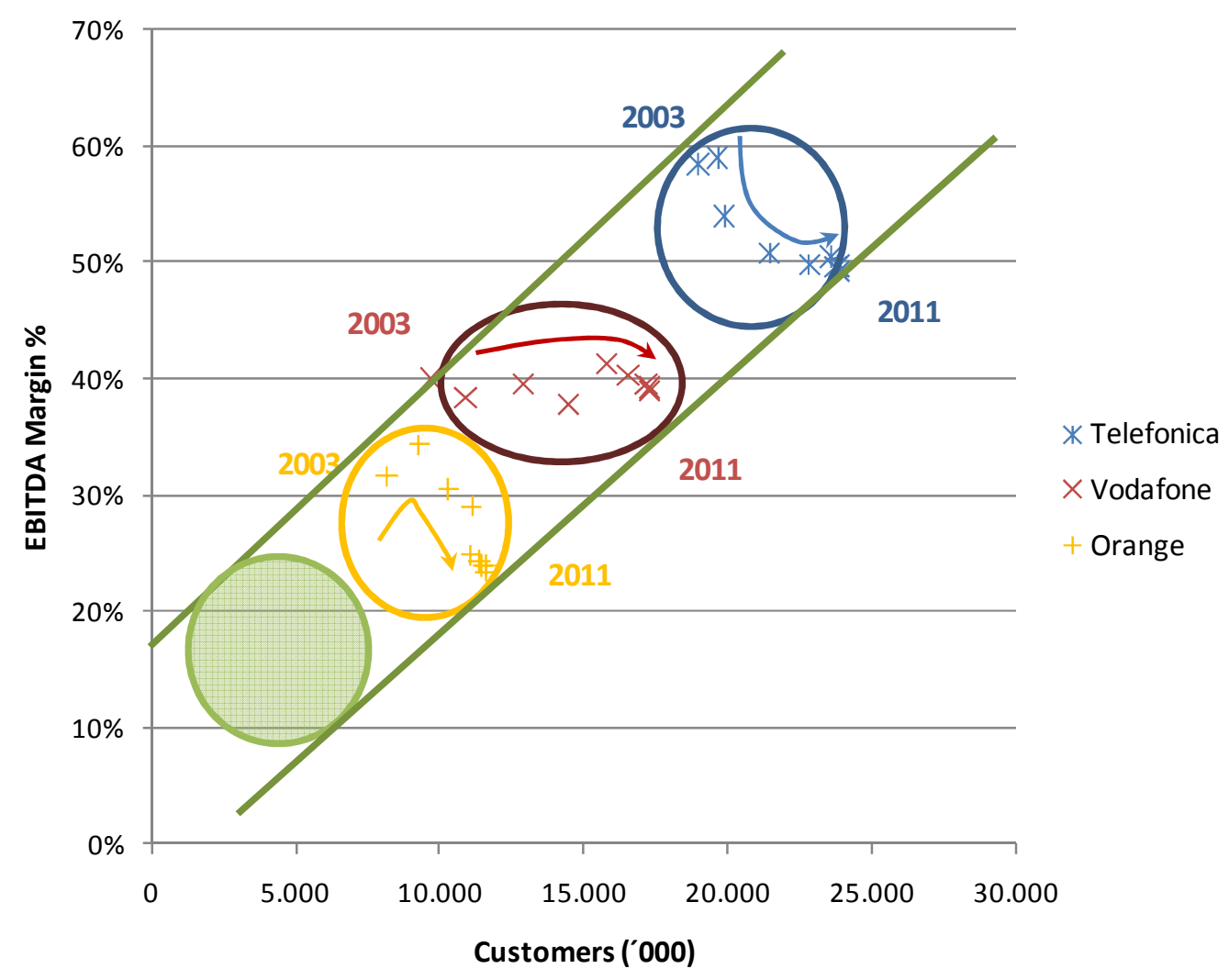

Source: Merrill Llynch \& Bank of America, Global Wireless Matrix 4Q09 and own analysis.

A consequence of the diagram presented in Figure 3 is that players already present in the market (incumbents) are able to extract more value from the same customers, because of having a higher EBITDA margin. Thus, there should be an option to sell to them the customer base at a premium. As we can see in the next section, we calculate the strike price of the option to abandon based on this fact.

As a starting point of the valuation, we calculate the NPV of Yoigo, the fourth player in the Spanish mobile telephony market, as if we were in 2006 at the moment of launching the 
company. In order to do that we make some assumptions regarding number of customers, ARPU (Average Revenue per User and Month), and also CAPEX (Capital Expenditures per year). We have made these assumptions based on our professional experience providing advice to the shareholders of Xfera Móviles S.A. between 2000 and 2004, and taking into account updated data from Investment Banks research (Merrill Lynch \& Bank of America, 2009), as detailed in Table 5.

Table 5: NPV of Yoigo and assumptions (figures in million $€$ and ('000) for customers).

\begin{tabular}{|c|c|c|c|c|c|c|c|c|c|c|c|c|}
\hline MARKET ( \#Subscribers) & 2006 & 2007 & 2008 & 2009 & 2010 & 2011 & 2012 & 2013 & 2014 & 2015 & 2016 & \\
\hline Total market & 47047 & 50155 & 52487 & 54055 & 54903 & 55522 & 56077 & 56638 & 57204 & 57776 & 58354 & \\
\hline Market growth & & $6,2 \%$ & $4,4 \%$ & $2,9 \%$ & $1,5 \%$ & $1,1 \%$ & $1,0 \%$ & $1,0 \%$ & $1,0 \%$ & $1,0 \%$ & $1,0 \%$ & \\
\hline INVESTMENT PROPOSAL & 2006 & 2007 & 2008 & 2009 & 2010 & 2011 & 2012 & 2013 & 2014 & 2015 & 2016 & \\
\hline Customers (Annual equivalent) & 0 & 500 & 1048 & 1620 & 2194 & 2774 & 3363 & 3963 & 4575 & 5198 & 5834 & \\
\hline Market share & & $1,0 \%$ & $2,0 \%$ & $3,0 \%$ & $4,0 \%$ & $5,0 \%$ & $6,0 \%$ & $7,0 \%$ & $8,0 \%$ & $9,0 \%$ & $10,0 \%$ & \\
\hline SALES & & 135 & 269 & 395 & 508 & 610 & 703 & 787 & 863 & 931 & 993 & \\
\hline ARPU (Monthly/customer) & 25 & 22,5 & 21,4 & 20,3 & 19,3 & 18,3 & 17,4 & 16,5 & 15,7 & 14,9 & 14,2 & \\
\hline EBITDA & & 27 & 54 & 79 & 102 & 122 & 141 & 157 & 173 & 186 & 199 & \\
\hline EBITDA / Sales (\%) & $20 \%$ & $20 \%$ & $20 \%$ & $20 \%$ & $20 \%$ & $20 \%$ & $20 \%$ & $20 \%$ & $20 \%$ & $20 \%$ & $20 \%$ & \\
\hline CAPEX & 300 & 25 & 50 & 75 & 100 & 100 & 100 & 100 & 100 & 100 & 100 & \\
\hline Capex / Sales (\%) & & $19 \%$ & $19 \%$ & $19 \%$ & $20 \%$ & $16 \%$ & $14 \%$ & $13 \%$ & $12 \%$ & $11 \%$ & $10 \%$ & \\
\hline Op FCF & -300 & 2 & 4 & 4 & 2 & 22 & 41 & 57 & 73 & 86 & 99 & 101 \\
\hline Op FCF including terminal value & -300 & 2 & 4 & 4 & 2 & 22 & 41 & 57 & 73 & 86 & 99 & 2.030 \\
\hline Accumulated Op. FCF & -300 & -298 & -294 & -290 & -289 & -267 & -226 & -169 & -96 & -10 & 88 & \\
\hline PV of FCF & 782 & 1168 & 1260 & 1356 & 1461 & 1576 & 1678 & 1769 & 1848 & 1918 & 1978 & 2030 \\
\hline FCF as $\%$ of NPV & $-38,4 \%$ & $0,2 \%$ & $0,3 \%$ & $0,3 \%$ & $0,1 \%$ & $1,4 \%$ & $2,4 \%$ & $3,2 \%$ & $3,9 \%$ & $4,5 \%$ & $5,0 \%$ & \\
\hline WACC & $8 \%$ & & & & & & & & & & & \\
\hline g & $3 \%$ & & & & & & & & & & & \\
\hline NPV & 782 & & & & & & & & & & & \\
\hline \multicolumn{13}{|l|}{ ASSUMPTIONS. } \\
\hline \multicolumn{13}{|l|}{ 1.- Customers. } \\
\hline \multicolumn{13}{|c|}{$\begin{array}{l}\text { - Customers starting pont: the first year } 1 \% \text { market share that equals } 500.000 \text {, real figure } 2007 \text { according to Bank of America (2009) was } 427.000 \text {. } \\
\text { - Customer growth: } 1 \% \text { annual growth. In line with Bank of America estimation for } 2009 \text { at } 3 \% \text {. }\end{array}$} \\
\hline \multicolumn{13}{|c|}{ 2.- ARPU (Average monthly total revenue per user) } \\
\hline \multicolumn{13}{|c|}{ - Starting point: $22,5 €$ in $2007,10 \%$ under Oranges ARPU. } \\
\hline \multicolumn{13}{|c|}{$\begin{array}{l}\text { - Evolution: -5\%/yr. decrease in line with 2003-2008 average market evolution (-7\%) according to CMT (Comisión del Mercado de las Telecomunicaciones) } \\
\text { and with estimations of Bank of America of } 20 € \text { for Yoigo in } 2009 .\end{array}$} \\
\hline \multicolumn{13}{|l|}{ 3.- EBITDA } \\
\hline \multicolumn{13}{|c|}{ - 20\% in line with Bank of America estimation for 2009} \\
\hline \multicolumn{13}{|c|}{ - Evolution: constant while being under $10 \%$ market share. } \\
\hline \multicolumn{13}{|l|}{ 4.- CAPEX } \\
\hline \multicolumn{13}{|c|}{$\begin{array}{l}\text { - Initial investment of } 300 \mathrm{~m} € \text { to develop a network of } 3.000 \text { sites according to our estimation of number of sites. (aproximately } 1 / 3 \text { Oranges network). } \\
\text { - Evolution: around } 20 \% \text { sales until it reaches a comparable size vs. current players that are at } 10 \%-12 \% \text { Capex/sales. }\end{array}$} \\
\hline \multicolumn{13}{|l|}{ 5.- WACC and g } \\
\hline - WACC $=8 \%$ in line with Bank of & ric & ati & Tel & & Span & bil & & & & & & \\
\hline 20 ascoling to ar ano & & & & & & & & & & & & \\
\hline
\end{tabular}

Source: Own analysis and market figures based Merrill Llynch \& Bank of America, Global Wireless Matrix 4Q09.

As presented in previous Table 5, the NPV of the investment proposal is positive at 782 million $€$, which allows us to justify the decision taken by the Yoigo board to take part in the Spanish mobile telecommunications market. However, we can make several comments in order to provide a better understanding of this valuation. Fistly, we can see that the launching of Yoigo requires a significant investment, with a peak funding of 300 million $€$, and only, after ten years of operation, the company is able to reach positive accumulated 
free cash flow. Secondly, we can see that the NPV lies mainly in the terminal value of the investment (2 $030 \mathrm{m€}$ in the year 2017) which depends critically of the cash flows growth rate " $g$ ". Thirdly, we assume the WACC to be $8 \%$, it is based in the figures used by investment banks such as Merrill Lynch Bank of America for Telefónica, and currently $8 \%$ is also utilized frequently in the Spanish mobile telecom industry to value every player independently of its size, it is due to the difficulty to assume a different level of risk in the long run for a similar móbile operator - Yoigo is owned TeliaSonera, the large and experienced sweden mobile operator - operating in the same market.

The Figure 4 shows the amount of initial disbursement and the evolution of flows, without discounting, between 2006 and 2016 (expressed in million €) and before considering the terminal value. As we mention before, the company reach positive accumulated free cash flow after ten years of operations.

Fig. 4: Cash flow evolution 2006 - 2016 (million

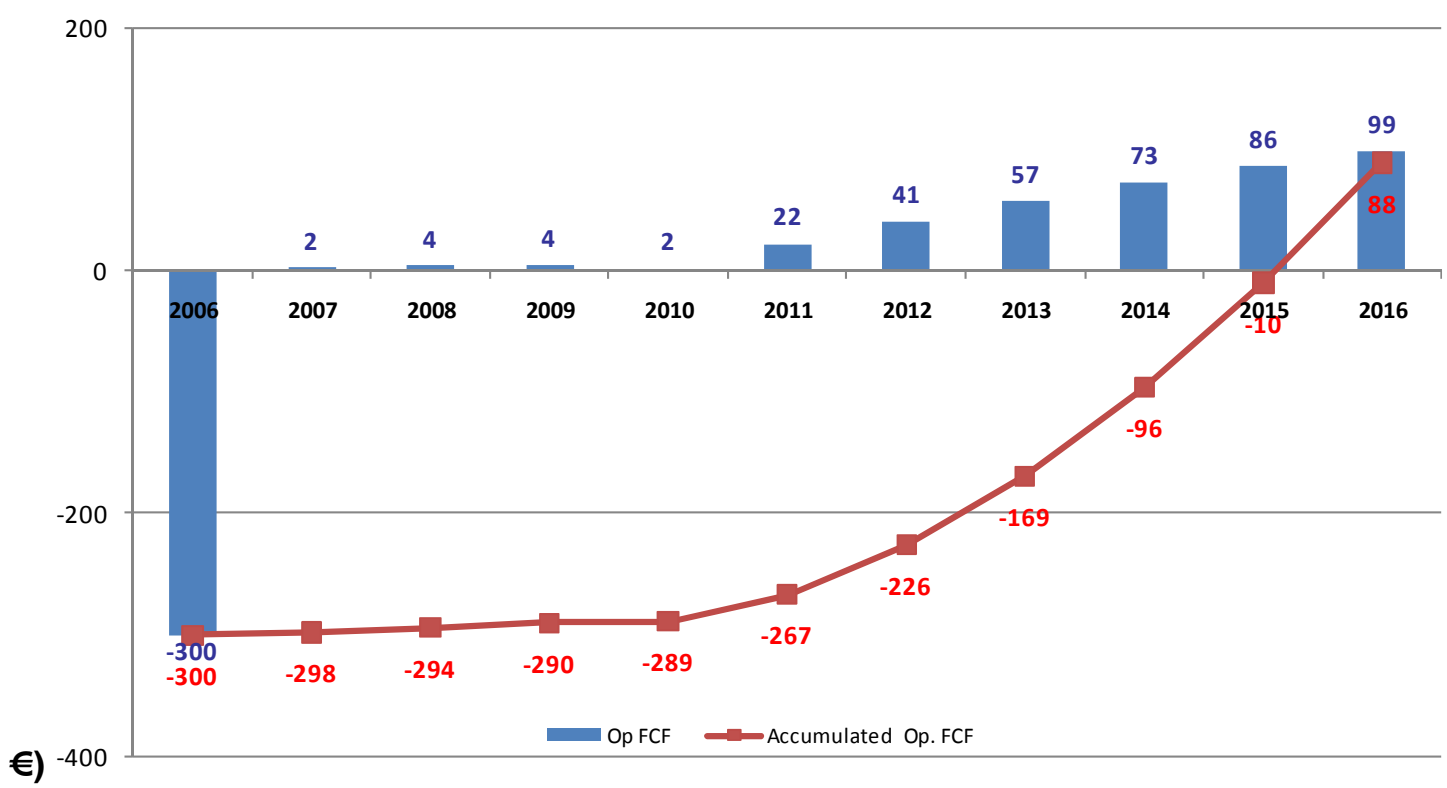

\subsection{Second step: Modeling the uncertainty using event trees}

Once we have estimated the NPV of the new entrant Yoigo, we proceed to model the causal uncertainties of the investment. In this case, we consider that the major source of uncertainty is the evolution in number of customers because, as we can see in Table 6, price variations 
are strongly correlated to customers growth rate. Thus, in the Spanish market for the period between 2002 and 2008 we have found a slope between customers growth rate and price variations (in percentage) of -0.6 , meaning that $1 \%$ market growth relates to a $0.6 \%$ price decrease, with a $\mathrm{R}^{2}$ factor of $99.1 \%$.

Table 6: Correlation between customer growth rate and price decrease in the Spanish market

\begin{tabular}{|c|c|c|c|c|c|c|c|}
\hline Evolution & 2002 & 2003 & 2004 & 2005 & 2006 & 2007 & 2008 \\
\hline Total market customers ('000) & 33530 & 37507 & 39161 & 43114 & 47047 & 50155 & 52487 \\
\hline (1) \% Growth & & $12 \%$ & $4 \%$ & $10 \%$ & $9 \%$ & $7 \%$ & $5 \%$ \\
\hline Average market ARPU ( $€ /$ month) & 25,0 & 23,5 & 22,8 & 20,0 & 18,4 & 17,2 & 16,3 \\
\hline (2) \% decrease & & $-6 \%$ & $-3 \%$ & $-12 \%$ & $-8 \%$ & $-6 \%$ & $-5 \%$ \\
\hline Slope between ( 1 and 2 ) & $-0,60$ & & & & & & \\
\hline R2 between (1 and 2 ) & $99,1 \%$ & & & & & & \\
\hline
\end{tabular}

Source: Own analysis from CMT 2009 and Merrill Llynch \& Bank of America Global Matrix, 2009.

Due to the nature of the project (a startup), the short life of the industry -the digital mobile telephony sector in Spain started in 1995- but also due to the evolution of the market, that has grown up very quickly, it would be difficult to assume that past years growth figures would be replicated. Consequently we use management estimates, as presented by Copeland and Antikarov (2001) to model the source of uncertainty number of customers. We assume a estimation that the total number of customers will be over 1 million by 2016. To estimate the volatility we assume lognormal distribution and, thus, we follow the equation recommended by Copeland and Antikarov (2001).

$$
\sigma=\frac{\sum_{i=0}^{n} r_{j}-\ln \left(\frac{V_{T}^{\text {lower }}}{V_{0}}\right)}{2 \sqrt{T}}
$$

were $T$ is the number of periods considered, $\Sigma r_{i}$ is the sum of the period growths, $V_{0}$ is the starting number of customers (we assume 0.5 million after 1 year, -reality has been 0.43 million), and $V_{T}^{\text {Lower }}$ is the lower forecasted number of customers, representing the worst case scenario according to management expectations at the end of the periods considered. We assume this worst case to be 1 million customers by 2016 .

Next we run Monte Carlo simulation. For each year we define a log-normally distributed random variable, customer evolution $(Q)$. Where $\varepsilon$ is a random number $N(0,1)$ and $\mu$ is the average growth for the periods considered.

$$
Q_{t}=Q_{t-1} e^{(\mu t+\sigma \varepsilon \sqrt{t})}
$$

As we mention before, we assume that price variation is strongly correlated with the customer evolution, being the $\mathrm{R}^{2}$ of the regression between customers growth rate and price 
variations (in percentage) of $99.1 \%$ shown in Table 6 . Every time we run Monte Carlo Simulation, price variations are also run.

Using this process we obtain many simulated sets of customers and ARPUs for the forecasted years. Once these values are simulated at different time intervals, we obtain the value of the flows corresponding to these simulations and from these the current value of the project at every moment.

Because Samuelson theorem ${ }^{1}$ is based on the rate of the asset considered, the current values of the project obtained from the simulations must be processed in rates of return using the following relationship,

$$
z_{n}=\ln \left[\frac{P V_{1, n}+F C F_{1, n}}{P V_{0}}\right]
$$

where $z_{n}$ variables represent the values obtained for continuous performance rates of the project value between period $t-1$ and $t$, and $n$ is the number of simulations. Note that in the above expression $\mathrm{PV}_{0}$ variable is constant and coincides with the current value of the project flow without uncertainty, while $\mathrm{PV}_{1}$ is calculated as

$$
P V_{1, n}=\sum_{t=2}^{T} \frac{F C F t, n}{(1+W A C C)^{t-1}}
$$

For 10000 trials, the distribution of the rate of return for the project NPV is lognormal with a mean value of $8.4 \%$. The volatility (standard deviation) of the rate of return is $21.5 \%$.

\subsection{Third step: Calculation on the strike price of the option to abandon}

Our thesis is that the company is assuming a risky investment opportunity because it has always the option to abandon the business if it does not perform adequately and does not reach the financial targets foreseen in terms of NPV. Specifically, the shareholders could decide to sell the business; and, due to the economies of scale, a higher value could be extracted from the same customers.

\footnotetext{
${ }^{1}$ Samuelson theorem states that the rate of return of an asset follow a random walk whatever the evolution of the flows generated by those assets are expected in the future, given that investors have complete information on these flows.

Following Copeland and Antikarov, the application of this theorem is very useful for valuing real options, because if all sources of uncertainty affecting the flows of a project are reducet to a single uncertainty - the rate of return of the project - and if this rate of return follows a random walk, then you can use a binomial framework for project appraisal.
} 
At this point it is important to mention the sensitivity of the NPV to EBITDA margin variations. In our assumptions we have considered an EBITDA margin for Yoigo of $20 \%$, and as it can be seen in the Table 7, a $5 \%$ increase in the EBITDA margin, from $20 \%$ to $25 \%$ means that the company increases its NPV in $80 \%$ from $782 \mathrm{~m} €$ to $1408 \mathrm{~m} €$.

This means that incumbent operators with higher EBITDA margins are able to extract much more value from the same customers so they would be willing to pay a premium for Yoigo business.

Table 7: Sensitivity of NPV (million $€$ ) to EBITDA margin variations.

\begin{tabular}{|ccc|}
\hline EBITDA Margin & NPV & Diference vs. 20\% \\
\hline $15 \%$ & 156 & $-80 \%$ \\
$20 \%$ & 782 & $0 \%$ \\
$25 \%$ & 1408 & $80 \%$ \\
$30 \%$ & 2034 & $160 \%$ \\
$35 \%$ & 2660 & $240 \%$
\end{tabular}

In the Spanish mobile market, the closest competitor to Yoigo is Orange, which has a 24\% EBITDA margin in 2009 (Merryl Llynch \& Bank of American, 2009). Thus, we could assume that the company resulting from a potential merge (Orange plus Yoigo) could have at least an EBITDA margin of $25 \%{ }^{2}$.

Although Movistar or Vodafone could be the ones that potentially could extract more value from Yoigo customers, the reality is that they would face relevant issues to serve a lower quality customer base -as reflected in their ARPU- such as having to offer lower tariffs to their current customer base. Even more relevant could be the possibility of losing these custormer in favour of Orange that is offering cheaper tariffs and is used to serve that customer profile. On the other hand, Orange customers are much more similar -in terms of ARPU- to Yoigo customers, and they also have the incentive to increase its EBITDA margin through merging operations (proportionally more than Movistar or Vodafone). Consequently, we assume that the option to abandon would be to sell the company, and the most likely scenario should be that of a deal between the two smaller players: Orange and Yoigo ${ }^{3}$.

\footnotetext{
${ }^{2}$ In our case we assume that there are not regulatory restrictions to sell - or hire - mobile frequiencies or mobile licences, which is the guideline European regulation is following, it could be different in other regions or countries.

${ }^{3}$ A similar situation happened in the UK in 2009 when T-mobile and Orange merged their operations, although other alternatives could also be taken into account.
} 
The strike price of the option to abandon is calculated as the increase in NPV due to higher EBITDA margins that would be generated from the same customers by an alternative player with larger scale. In our case the strike price would be based in a 5\% EBITDA increase that would generate an $80 \%$ NPV increase.

Consequently, the strike price is variable since will change depending on the simulated values for the number of customers. That is, although the strike price is based on a fixed EBITDA margin increase that generates a fixed NPV increase, the value depends upon the customers reached in every period. Additionally a sensitivity analysis could be made using a range of incremental EBITDAs (i.e. between $2.5 \%$ and $7.5 \%$ instead of a fixed $5 \%)$. We think that this approach is a much more realistic manner than the traditional approaches based in a fixed strike price of the option to abandon which does not change during the life of the project, and also helps to gain a deeper understanding of the value of the business.

\subsection{Step four: Total value of the investment opportunity}

To calculate the value of the company including the option to abandon we use a discrete multiplicative binomial event tree. Differently from models in continuous time, such as those by Black and Scholes (1973) and Merton (1973), a discrete setting helps to clarify the economic principles underlying option pricing. The main reason to use a discrete setting, however, is that there are not closed form solutions in continuous time for American put options as it is presented in the case. Binomial trees provide a simple set up to value such American derivatives.

To construct the event tree of the NPV we use upside change " $u$ " and downside change " $d$ " as proposed by Cox, Ross, and Rubinstein (1979).

$$
u=e^{a \sqrt{\tau}} \quad d=e^{-a \sqrt{\tau}}
$$

being $\sigma$ the volatility of the underlying asset (which is the Present Value) and the time step. This way we find " $u$ " and " $d$ " values, and build a binomial tree that we calculate following the process proposed by Copeland and Antikarov (2001). Table 8 shows the event tree before introducing options. 
Table 8: Event tree (million $€$ )

$\mathrm{Up}(\mathrm{u})=1.239984$

$\operatorname{Down}(\mathrm{d})=0.806461$

Present Value before dividends (dividends $=$ CF)

\begin{tabular}{|c|c|c|c|c|c|c|c|c|c|c|}
\hline 2006 & 2007 & 2008 & 2009 & 2010 & 2011 & 2012 & 2013 & 2014 & 2015 & 2016 \\
\hline \multirow[t]{2}{*}{1081.9} & 1168.4 & 1446.4 & 1788.1 & 2210.7 & 2738.3 & 3347.3 & 4047.9 & 4851.2 & 5769.8 & 6817.6 \\
\hline & & 940.7 & 1162.9 & 1437.8 & 1780.9 & 2177.0 & 2632.6 & 3155.1 & 3752.6 & 4434.1 \\
\hline Capex (Yr 1) & & & 756.3 & 935.1 & 1158.3 & 1415.9 & 1712.2 & 2052.0 & 2440.6 & 2883.8 \\
\hline \multirow[t]{6}{*}{300.0} & & & & 608.2 & 753.3 & 920.9 & 1113.6 & 1334.6 & 1587.3 & 1875.6 \\
\hline & & & & & 489.9 & 598.9 & 724.3 & 868.0 & 1032.4 & 1219.8 \\
\hline & & & & & & 389.5 & 471.0 & 564.5 & 671.4 & 793.4 \\
\hline & & \multicolumn{3}{|c|}{$P V_{1}=P V_{0} \times u$ (or) $P V_{0} \times d$} & & & 306.4 & 367.2 & 436.7 & 515.9 \\
\hline & & & & & & & & & 184.7 & 218.3 \\
\hline & & & & & & & & & & 142.0 \\
\hline
\end{tabular}

The next step is to calculate the effect of the FCF in the present value of every single period; we calculate it as a percentage of the present value as described by Copeland and Antikarov (2001) and presented in Table 9.

Table 9: CF of every period as a percentage of PV (million $€$ )

\begin{tabular}{|c|c|c|c|c|c|c|c|c|c|c|}
\hline & CF a & PV & & & & & & & & \\
\hline 2006 & 2007 & 2008 & 2009 & 2010 & 2011 & 2012 & 2013 & 2014 & 2015 & 2016 \\
\hline$-27.7 \%$ & $0.2 \%$ & $0.3 \%$ & $0.3 \%$ & $0.1 \%$ & $1.4 \%$ & $2.5 \%$ & $3.3 \%$ & $4.1 \%$ & $4.7 \%$ & $5.2 \%$ \\
\hline
\end{tabular}

\begin{tabular}{|c|c|c|c|c|c|c|c|c|c|c|}
\hline \multirow[b]{2}{*}{2006} & \multicolumn{10}{|c|}{ culated fo } \\
\hline & 2007 & 2008 & 2009 & 2010 & 2011 & 2012 & 2013 & 2014 & 2015 & 2016 \\
\hline \multirow[t]{10}{*}{-300.0} & 2.0 & 4.3 & 5.2 & 2.4 & 38.8 & 82.8 & 135.6 & 198.1 & 271.6 & 357.4 \\
\hline & & 2.8 & 3.4 & 1.6 & 25.2 & 53.9 & 88.2 & 128.8 & 176.7 & 232.5 \\
\hline & & & 2.2 & 1.0 & 16.4 & 35.0 & 57.3 & 83.8 & 114.9 & 151.2 \\
\hline & & & & 0.7 & 10.7 & 22.8 & 37.3 & 54.5 & 74.7 & 98.3 \\
\hline & & & & & 6.9 & 14.8 & 24.3 & 35.4 & 48.6 & 64.0 \\
\hline & & & & & & 9.6 & 15.8 & 23.1 & 31.6 & 41.6 \\
\hline & & $\mathrm{CF}=$ & NPV) $\times$ & before & ends) & & 10.3 & 15.0 & 20.6 & 27.1 \\
\hline & & & & & & & & 9.8 & 13.4 & 17.6 \\
\hline & & & & & & & & & 8.7 & 11.4 \\
\hline & & & & & & & & & & 7.4 \\
\hline
\end{tabular}

Now, we are able to calculate the Binomial tree extracting the FCF for every period and identifying the cells were the value is under the expected present value in the previous DCF valuation, as presented in Table 10. We have defined the criteria that we would abandon the business when that happens because that would mean that we are not reaching our initial financial targets.

The strike price of the option in those cases would be the present value of the business in that moment incremented by the $80 \%$ due to the higher NPV extracted to the customer base by a competitor when being sold. 
Table 10: Current tree ex outflows identifying cells where PV is under expectations (million $€$ )

\begin{tabular}{|c|c|c|c|c|c|c|c|c|c|c|}
\hline 2006 & 2007 & 2008 & 2009 & 2010 & 2011 & 2012 & 2013 & 2014 & 2015 & 2016 \\
\hline 781.9 & 1168.4 & 1259.8 & 1356.5 & 1460.7 & 1575.8 & 1678.1 & 1768.6 & 1848.2 & 1917.8 & 1978.1 \\
\hline
\end{tabular}

Current tree ex-CF

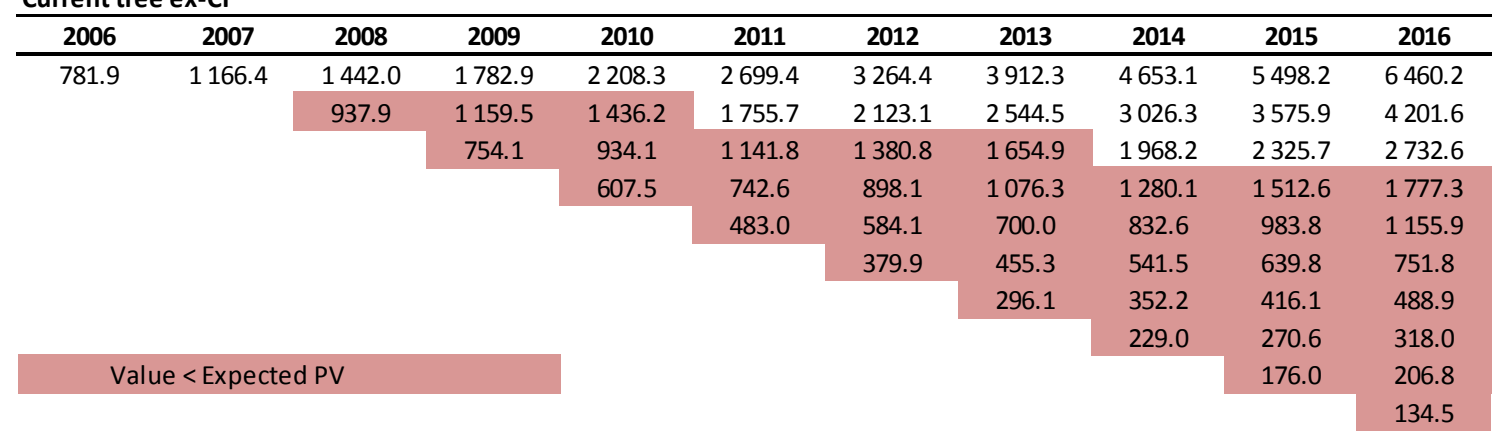

To calculate the value of the option in every period we use the risk neutral probability approach, where $r f$ is the risk free rate, in our case we use $3.53 \%$ which is an average interest rate of Spanish Public debt that we have calculated for 2006 (Tesoro Público, 2009), and " $u$ " and " $d$ " are the up and down movements presented before.

$$
q=\frac{1+r f-d}{u-d} \quad, \quad q=1-q
$$

Applying these probabilities, we obtain the value of the option to abandon in a recursive way, starting from the final period of time and moving back until the begining. Thus, we obtain a present value for the option to abandon of 555 million $€$, as it is shown in Table 11. This value of the option is clearly positive and can be added to the present value of the business without flexibility utilizing DCF at 782 million to provide a better estimation of the investment value. 
Table 11: Value of the option to abandon due to incremental EBITDA (NPV* $(1+0.8))($ million $€$ )

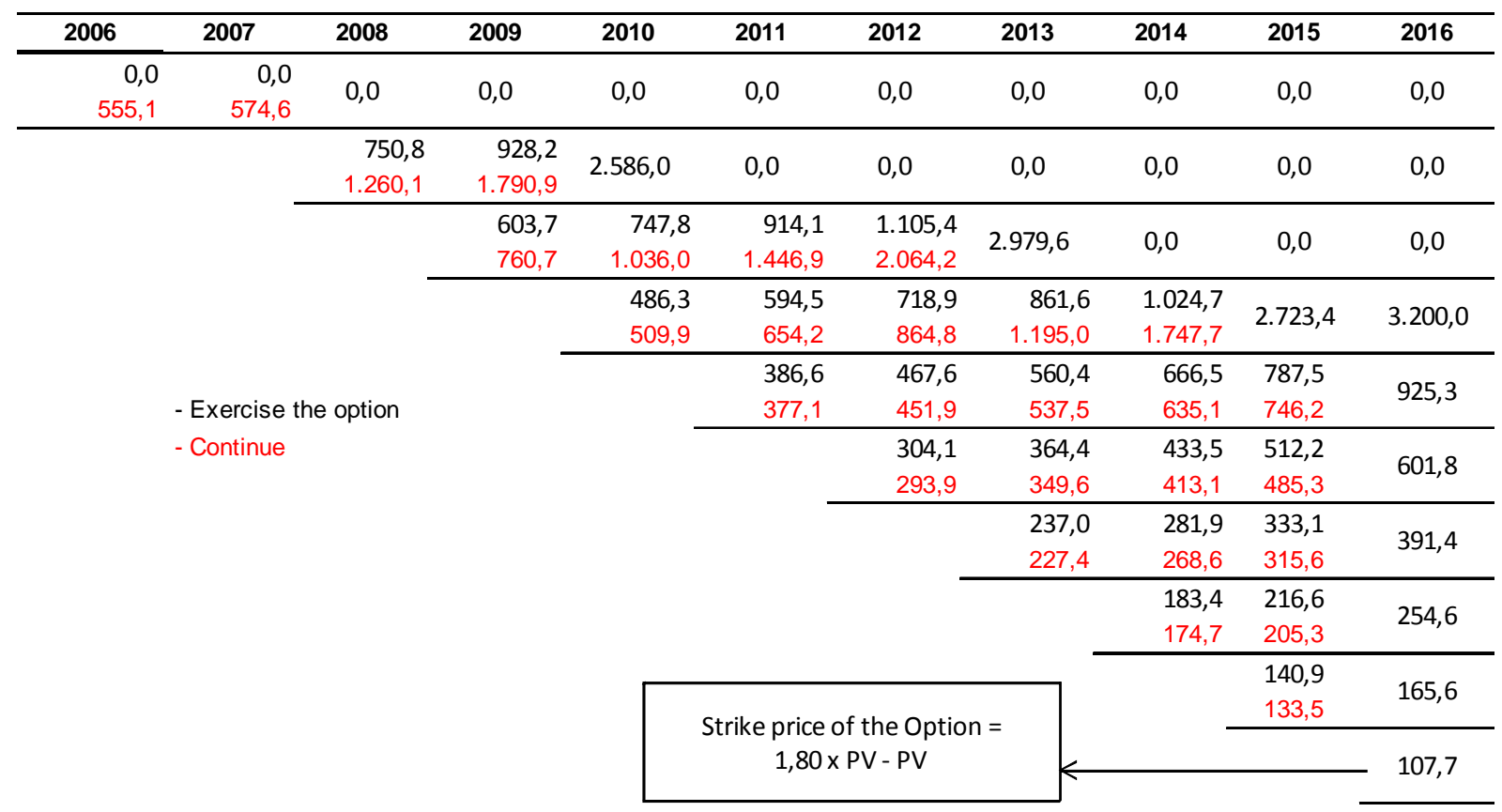

As represented in Figure 5 the total value of the new entrant, including the option to abandon, would be 1336.9 million $€$ if we consider a 80\% NPV increase due to 5\% EBITDA increase. Although the traditional NPV of Yoigo investment allows us to accept the project, a correct valuation of the new entrant requires consider all sources of value. Taking into account the option to abandon, the Extended NPV of Yoigo is higher than the traditional NPV and so it is much easier to explain that the shareholders should assume this investment proposal.

Fig. 5: Total value of the business including the option (million $€$ ).

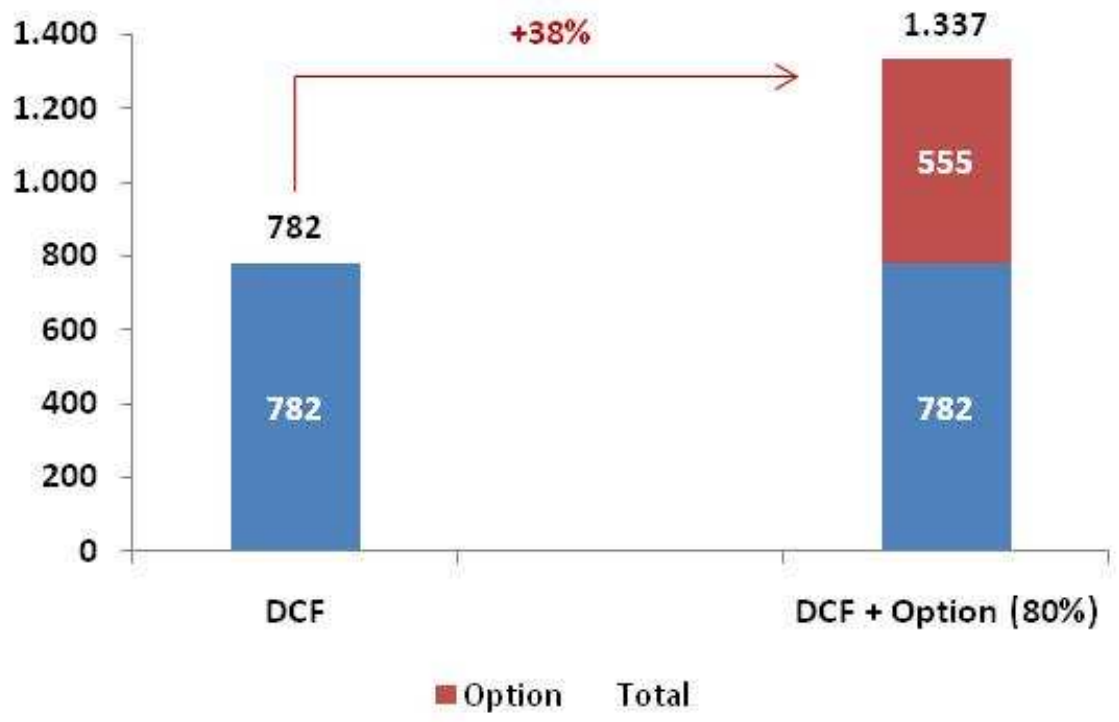




\section{CONCLUSIONS}

This paper presents an in-depth analysis of the sources of value for the case of an investment of a new entrant in an oligopolistic market. We approach the creation of value in the decision of launching Yoigo, the fourth operator in the Spanish mobile telecommunications market, through the real options method. From this perspective, the value of the investment in launching Yoigo derives jointly from its expected cash flows without flexibility and the option to abandon de market by selling its business or merging with a competitor.

Each component of the value of the new entrant has to be evaluated with appropriate techniques. Thus, for valuing the value of the investment without flexibility we use models based on discounted cash flows and for valuing the option to abandon we employ Real Option techniques.

Our analysis of this real investment case provides new evidence about the relevance of sources of value which differ from direct cash flow. The economies of scale present in the mobile telecommunicatins industry allow a new entrant in the market to consider the option to sell its customers base to larger players if it does not reach its business targets, because they are able to extract more value from the same customer base.

To estimate the value of the option to abandon the industry, we apply the proposal of Copeland and Antikarov (2001), which is adapted to the nature of the investment analysed. One of the most important parameters in the valuation of the option is the strike price. Again, due to the economies of scale present in the industry, the strike price of the option to abandon can be calculated using the incremental NPV caused by higher EBITDA margins. This is a relevant point in the valuation and is a distinguishing element vs. traditional methods were the abandonment value did not change during the life of the project.

We have found that the value of the option to abandon to be positive and contribute to justify the investment strategy made at the time by Yoigo. A correct valuation of the new entrant in a oligopolistic market requires consider all sources of value. Taking into account the option to abandon, the Extended NPV of Yoigo is higher than the traditional NPV and so it is much easier to explain that the shareholders should assume this investment

proposal. 


\section{REFERENCES}

BBC (2009) Press Release on "T-Mobile and Orange merger", 2009, available at http://news.bbc.co.uk/2/hi/8243226.stm

Black, F. and Scholes, M. (1973): "The Pricing of Options and Corporate Liabilities". Journal of Political Economy, no 81, pág.: 637-659.

CMT Informe anual 2009.

CMT Quarterly Report, Q3, 2009.

Copeland, T. E. and Antikarov, V. (2001): Real Options. A practitioner's guide. Ed.: Texere New York.

Cox, J.; Ross, S. and Rubinstein, M. (1979): "Option Pricing: A Simplified Approach". Journal of Financial Economics, ํo 7, pág.: 229-64.

Damodaran, A. (2002): Investment Valuation (Second Edition, chapter 29). Ed.: Wiley Finance, New York.

Katz, M. L. and Shapiro, C. (1985): "Network externalities, competition and compatibility". American Economics Review, № 75, pág.: 425-440.

Katz, M. L. and Shapiro, C. (1986): "Technology adoption in the presence of network externalities”. Journal of Political Economy, no 94, pág.: 822-841.

Kotler, P. and Keller, K. L. (2009): Dirección de Marketing (12 ${ }^{\text {th }}$ Edition, chapter 11). Ed.: Pearson Educación S.A., Madrid.

Merton, R. C. (1973): "Theory of Rational Option Pricing". Bell Journal of Economics and Management Science, ํo 4, pág.: 141-183.

Riihimäki, V. (2006): Real Option Valuation of Broadband Access Networks - Statistical Analysis of WiMAX and ADSL Investments. Licentiate Thesis, Department of Electrical and Communications Engineering, Helsinki University of Technology, Espoo.

Samuelson, P. A. (1965): "Rational Theory of Warrant Price". Industrial Management Review, pp. 13-39.

Samuelson, P. A. and Nordhaus, W. D. (1986): Economía (12 ${ }^{\text {th }}$ Edition, chapter 23). Ed.: MacGraw Hill, Mexico.

Tesoro Público (2009): "Tipos de interés medios de la deuda del Estado en moneda Nacional", available http://www.tesoro.es/doc/SP/home/estadistica/03.pdf 